\title{
Effects of supplemental chromium propionate and rumen-protected amino acids on productivity, diet digestibility, and energy balance of peak-lactation dairy cattle
}

\author{
C. F. Vargas-Rodriguez, ${ }^{\star}$ K. Yuan, ${ }^{*}$ E. C. Titgemeyer, ${ }^{*}$ L. K. Mamedova, ${ }^{*}$ K. E. Griswold, $†$ and B. J. Bradford ${ }^{* 1}$ \\ *Department of Animal Sciences and Industry, Kansas State University, Manhattan 66506 \\ †Kemin Industries, Des Moines, IA 50317
}

\section{ABSTRACT}

Chromium ( $\mathrm{Cr}$ ) feeding in early lactation increased milk production in some studies, but responses to dietary $\mathrm{Cr}$ during peak lactation have not been evaluated. Furthermore, interactions of essential amino acids (AA) and Cr have not been explored. Our objective was to evaluate responses to $\mathrm{CrPr}$ (KemTRACE chromium propionate $0.04 \%$, Kemin Industries Inc., Des Moines, IA) and rumen-protected Lys (LysiPEARL, Kemin Industries Inc.) and Met (MetiPEARL, Kemin Industries Inc.) and their interaction in peak-lactation cows. Forty-eight individually fed Holstein cows (21 primiparous, 27 multiparous, $38 \pm 15 \mathrm{~d}$ in milk) were stratified by calving date in 12 blocks and randomly assigned to 1 of 4 treatments within block. Treatments were control, $\mathrm{CrPr}(8 \mathrm{mg} / \mathrm{d}$ of $\mathrm{Cr})$, RPLM (10 $\mathrm{g} / \mathrm{d}$ of Lys and $5 \mathrm{~g} / \mathrm{d}$ of Met, intestinally available), or $\mathrm{CrPr}$ plus RPLM. Treatments were premixed with ground corn and top-dressed at $200 \mathrm{~g} / \mathrm{d}$ for $35 \mathrm{~d}$. Diets consisted of corn silage, alfalfa hay, and concentrates, providing approximately $17 \%$ crude protein, $31 \%$ neutral detergent fiber, and 40\% nonfiber carbohydrates. Dry matter intake (DMI) significantly increased with the inclusion of $\mathrm{CrPr}(22.2$ vs. $20.8 \pm 0.67 \mathrm{~kg} / \mathrm{d})$, and energy-corrected milk (ECM) yield tended to increase. In addition, $\mathrm{CrPr}$ increased milk protein yield and tended to increase DMI in primiparous cows but not in multiparous cows. A $\mathrm{CrPr} \times$ week interaction was detected for milk lactose content, which was increased by $\mathrm{CrPr}$ during wk 1 only (4.99 vs. $4.88 \pm 0.036 \%$ ). As a proportion of plasma AA, lysine increased and methionine tended to increase in response to RPLM, but the inclusion of RPLM decreased $\mathrm{N}$ efficiency (milk protein N:N intake). Digestible energy intake, gross energy digestibility, and energy balance were not affected by treatments. We observed no treatment effects on feed efficiency or changes in body weight or body

Received November 25, 2013.

Accepted February 15, 2014.

${ }^{1}$ Corresponding author: bbradfor@ksu.edu condition score. In summary, feeding $\mathrm{CrPr}$ increased DMI and tended to increase ECM in cows fed for 5 wk near peak lactation, with primiparous cows showing greater responses in DMI and milk protein yield than multiparous cows.

Key words: lysine, methionine, chromium, essential amino acid

\section{INTRODUCTION}

After parturition, cows must adapt to milk secretion, but their daily DMI rarely matches the nutrient demands for that activity (Dalbach et al., 2011). Because of these extremely high nutrient requirements, cows near peak lactation are most likely to experience AA deficiencies, which can limit peak milk and, in turn, decrease whole-lactation productivity.

Chromium ( $\mathrm{Cr}$ ) is involved in many metabolic functions (Mertz, 1993; Bryan et al., 2004); it activates certain enzymes and stabilizes AA and nucleic acids (NRC, 1997; Khalili et al., 2012). Some studies utilized supplemental $\mathrm{Cr}$ in diets for lactating cattle and reported increases in milk production (Hayirli et al., 2001; McNamara and Valdez, 2005), whereas others detected enhanced immune responsiveness and disease resistance, particularly in animals under stress conditions (Spears et al., 2012).

It is also known that $\mathrm{Cr}$ can potentiate the action of insulin by binding to intracellular insulin receptor sites and promoting signal transduction (Kegley et al., 2000), thereby enhancing carbohydrate metabolism. In addition, $\mathrm{Cr}$ can alter protein synthesis (Gentry et al., 1999); although the mechanisms underlying this effect are not completely understood, the effect of $\mathrm{Cr}$ on insulin sensitivity has been clearly demonstrated in cattle (Sumner et al., 2007), and insulin signaling promotes protein synthesis. However, there is currently no information about interactions between AA nutrition and $\mathrm{Cr}$ supplementation in dairy cattle. Therefore, a critical need exists to further explore responses to $\mathrm{Cr}$ in the presence and absence of supplemental AA near peak lactation. 


\section{MATERIALS AND METHODS}

The Kansas State University Institutional Animal Care and Use Committee approved all experimental procedures.

\section{Design and Treatments}

Forty-eight lactating Holstein cows (21 primiparous and 27 multiparous, $38 \pm 15$ DIM) were used in a randomized complete block design with 4 treatments. The cows were stratified by calving date in 12 blocks, and assigned randomly to treatments within block.

All cows were housed in tie-stalls and individually fed a common diet (Table 1). Analysis by the Cornell Net Carbohydrate and Protein System version 6.1 (NDS version 3, Ruminant Management \& Nutrition, Reggio Emilia, Italy) estimated metabolizable Lys supply at $148 \mathrm{~g} / \mathrm{d}(6.38 \%$ of MP) and metabolizable Met supply at $47 \mathrm{~g} / \mathrm{d}(2.03 \%$ of MP) with $22 \mathrm{~kg} / \mathrm{d}$ DMI in the control diet. Treatments were premixed with ground corn and offered as a top-dress at a rate of $200 \mathrm{~g} /$ cow daily for 35 d. Treatments were control, $\mathrm{Cr}$ propionate $(\mathbf{C r P r} ; 8$ $\mathrm{mg} / \mathrm{d} \mathrm{Cr}$ in the form of $20 \mathrm{~g} / \mathrm{d}$ KemTRACE chromium propionate $0.04 \%$, Kemin Industries Inc., Des Moines, IA), rumen-protected lysine and methionine (RPLM; $10 \mathrm{~g} / \mathrm{d}$ lysine and $5 \mathrm{~g} / \mathrm{d}$ methionine, intestinally available), or both (CrPr+RPLM). The RPLM supplement was composed of $48.8 \mathrm{~g} / \mathrm{d}$ of LysiPEARL and 15.3 $\mathrm{g} / \mathrm{d}$ of MetiPEARL (Kemin Industries Inc.), and was predicted to provide Lys and Met supplies of 6.77 and $2.23 \%$ of MP, respectively. Cows were milked 3 times daily $(0300,1100$, and $1900 \mathrm{~h}$ ) and fed once daily (1600 h) for ad libitum intake, targeting 10\% daily refusals.

\section{Sample and Data Collection}

Feed offered and feed refused were measured for each cow daily to determine DMI. Milk yield was recorded for each cow daily. Body weights and BCS (Wildman et al., 1982) were measured on d 1 and 35. Milk samples were collected $3 \mathrm{~d}$ per week for milk composition analysis. Samples of feed ingredients were collected weekly and frozen for analysis. On d 19 to 21 and d 33 to 35, samples of TMR and feed refusals were collected daily and fecal samples were collected at 9-h intervals, representing every $3 \mathrm{~h}$ of a 24 -h period.

On d 21 and $35(1430 \mathrm{~h})$, approximately $7 \mathrm{~mL}$ of blood was collected from the coccygeal vessels into evacuated tubes containing K3-EDTA (Vacutainer, Becton Dickinson, Franklin Lakes, NJ). Samples were centrifuged at 2,000 $\times g$ for 15 min immediately after sample collection, and plasma was harvested and frozen at $-20^{\circ} \mathrm{C}$ until analysis.

\section{Sample Analysis}

Samples of diet ingredients, TMR, and feed refusals were dried in a $55^{\circ} \mathrm{C}$ forced air oven for $48 \mathrm{~h}$, composited by collection period (d 21 vs. 35), ground through a 1-mm screen (Wiley mill, Arthur H. Thomas, Swedesboro, NJ), and analyzed for DM, OM, CP, NDF, and ether extract $(\mathbf{E E})$. The DM content was determined by drying at $105^{\circ} \mathrm{C}$ in a forced-air oven for $16 \mathrm{~h}$. Ash concentration was determined after $4 \mathrm{~h}$ of oxidation at $500^{\circ} \mathrm{C}$ in a muffle furnace. Nitrogen content was determined by oxidation and detection of $\mathrm{N}_{2}$ (Leco Analyzer, Leco Corp., St. Joseph, MI). Concentration of NDF was determined using an Ankom Fiber Analyzer (An-

Table 1. Ingredient and nutritional composition of the basal diet

\begin{tabular}{|c|c|}
\hline Item & Value \\
\hline \multicolumn{2}{|l|}{ Ingredient, $\%$ of DM } \\
\hline Corn silage & 31.5 \\
\hline Alfalfa hay & 23.4 \\
\hline Wet corn gluten feed ${ }^{1}$ & 6.8 \\
\hline Ground corn & 23.1 \\
\hline Whole cottonseed & 4.6 \\
\hline Mechanically extracted soybean meal ${ }^{2}$ & 2.1 \\
\hline Solvent-extracted soybean meal & 5.1 \\
\hline Ca salts of long-chain fatty acids ${ }^{3}$ & 0.8 \\
\hline Micronutrient premix ${ }^{4}$ & 2.6 \\
\hline \multicolumn{2}{|l|}{ Nutrient, $\%$ of DM unless otherwise noted } \\
\hline $\mathrm{DM}, \%$ as-fed & 57.9 \\
\hline $\mathrm{OM}$ & 91.3 \\
\hline $\mathrm{CP}$ & 16.7 \\
\hline NDF & 31.7 \\
\hline $\mathrm{ADF}$ & 20.1 \\
\hline $\mathrm{fNDF}^{5}$ & 22.1 \\
\hline NFC & 39.8 \\
\hline Ether extract & 3.1 \\
\hline Gross energy, Mcal $/ \mathrm{kg}$ & 4.11 \\
\hline Digestible energy, ${ }^{6} \mathrm{Mcal} / \mathrm{kg}$ & 3.34 \\
\hline $\mathrm{ME},{ }^{7} \mathrm{Mcal} / \mathrm{kg}$ & 2.92 \\
\hline $\mathrm{NE}_{\mathrm{L}},{ }^{8} \mathrm{Mcal} / \mathrm{kg}$ & 1.87 \\
\hline Model-predicted $\mathrm{ME},{ }^{9} \mathrm{Mcal} / \mathrm{kg}$ & 2.50 \\
\hline
\end{tabular}

${ }^{1}$ SweetBran (Cargill Inc., Blair, NE).

${ }^{2}$ Soy Best (Grain States Soya, West Point, NE).

${ }^{3}$ Megalac-R (Church \& Dwight Co., Princeton, NJ).

${ }^{4}$ Premix consisted of $45.1 \%$ limestone, $32.2 \%$ sodium bicarbonate, $6.4 \%$ magnesium oxide, $5.2 \%$ sodium chloride, $5.2 \%$ vitamin $\mathrm{E}$ pre$\operatorname{mix}(44 \mathrm{IU} / \mathrm{g}), 0.45 \%$ vitamin A premix $(30 \mathrm{kIU} / \mathrm{g}), 0.19 \%$ vitamin D premix $(30 \mathrm{kIU} / \mathrm{g}), 2.1 \%$ 4-Plex (Zinpro Corp., Eden Prairie, MN; contains $2.58 \% \mathrm{Zn}, 1.48 \% \mathrm{Mn}, 0.90 \% \mathrm{Cu}, 0.18 \% \mathrm{Co}, 8.21 \%$ Met, and $3.80 \%$ Lys), $0.96 \%$ selenium premix (600 mg $/ \mathrm{kg} \mathrm{Se}$ ), $0.45 \%$ Zinpro 100 (Zinpro Corp.; contains $10 \% \mathrm{Zn}$ and $20 \%$ Met), $0.03 \%$ ethylenediamine dihydriodide premix (3.65\% I), 0.88\% Kallsil (Kemin Industries Inc., Des Moines, IA), and 0.88\% Myco CURB (Kemin Industries Inc.).

${ }^{5}$ Forage NDF.

${ }^{6}$ Digesible energy $(\mathrm{DE})=$ (gross energy $(\mathrm{GE})$ intake $-\mathrm{GE}$ in feces $) /$ DMI.

${ }^{7} \mathrm{ME}=[1.01 \times(\mathrm{DE}, \mathrm{Mcal} / \mathrm{kg})-0.45]+0.0046 \times($ ether extract, $\%,-3)$.

${ }^{8} \mathrm{NE}_{\mathrm{L}}=0.703 \times \mathrm{ME}(\mathrm{Mcal} / \mathrm{kg})-0.19+[(0.097 \times \mathrm{ME}, \mathrm{Mcal} / \mathrm{kg},+$ $0.19) / 97] \times[$ ether extract, $\%,-3]$.

${ }^{9} \mathrm{ME}$ predicted by CNCPS 6.1 (NDS version 3, Ruminant Management \& Nutrition, Reggio Emilia, Italy). 
kom Technology, Fairport, NY) including amylase and sodium sulfite (Van Soest et al., 1991). Crude fat was determined by ether extraction (AOAC International, 2000; method 920.9).

Milk samples were analyzed for concentration of fat, true protein, lactose (B-2000 Infrared Analyzer; Bentley Instruments, Chaska, MN), MUN (MUN spectrophotometer, Bentley Instruments), and somatic cells (SCC 500, Bentley Instruments) by Heart of America DHIA (Manhattan, KS). Plasma free AA were determined by HPLC as previously described (Brake et al., 2013). Plasma AA concentrations were expressed as a proportion of total free AA.

\section{Energy Balance}

The concentration of acid detergent insoluble ash (ADIA) was determined (Van Soest et al., 1991) in dried samples of feed ingredients, refusals, and feces. This parameter was used as an endogenous indigestible marker to estimate fecal output (Cochran et al., 1986). The gross energy (GE) content of feed, top-dressed treatments, refusals, and dried fecal samples were determined by bomb calorimetry. Intake of GE was calculated as GE in feed offered (calculated from analysis of feed ingredients) minus GE in refusals; fecal GE was subtracted to determine digestible energy (DE) intake. After calculating DE concentration of the diets by cow (DE intake/DMI), $\mathrm{ME}$ and $\mathrm{NE}_{\mathrm{L}}$ concentrations were calculated using the following formulas (NRC, 2001): $\mathrm{ME}(\mathrm{Mcal} / \mathrm{kg}$ of $\mathrm{DM})=[1.01 \times(\mathrm{DE}, \mathrm{Mcal} / \mathrm{kg})-0.45]$ $+0.0046 \times(\mathrm{EE}, \%,-3)$, and $\mathrm{NE}_{\mathrm{L}}(\mathrm{Mcal} / \mathrm{kg})=0.703$ $\times \mathrm{ME}(\mathrm{Mcal} / \mathrm{kg})-0.19+[(0.097 \times \mathrm{ME}, \mathrm{Mcal} / \mathrm{kg},+$ $0.19) / 97] \times(\mathrm{EE}, \%,-3)$. Intakes of $\mathrm{ME}$ and $\mathrm{NE}_{\mathrm{L}}$ were then determined by multiplying these concentrations by DMI. Milk energy output (Mcal) was calculated as $9.29 \times \mathrm{kg}$ of milk fat $+5.47 \times \mathrm{kg}$ of milk protein + $3.095 \times \mathrm{kg}$ of milk lactose, and maintenance energy requirements (Mcal/d) estimated as $0.08 \times \mathrm{kg}$ of $\mathrm{BW}^{0.75}$ (NRC, 2001). To determine $\mathrm{NE}_{\mathrm{L}}$ balance, milk and maintenance energy were subtracted from $\mathrm{NE}_{\mathrm{L}}$ intake.

\section{Statistical Analysis}

One cow on CrPr+RPLM developed severe mastitis on d 20 of treatment and was subsequently removed from the study. No data were collected from or analyzed for this cow. Milk and DMI data were averaged by week before analysis. Data were analyzed using the Mixed Procedure of SAS (version 9.2; SAS Institute, 2011) to assess the fixed effects of parity (primiparous vs. multiparous), time, CrPr, RPLM, and 2-, 3-, and 4-way interactions, and the random effect of block. With the exception of $\mathrm{CrPr} \times \mathrm{RPLM}$, interactions were removed from models when $P>0.30$. Repeated measures over time within cow were modeled with an autoregressive $[\mathrm{AR}(1)]$ covariance structure. Denominator degrees of freedom were estimated using the Kenward-Rogers method. Significance was declared at $P \leq 0.05$ and tendencies at $0.05<P<0.10$. Treatment means were separated with pair-wise $t$-tests when interactions were significant.

\section{RESULTS AND DISCUSSION}

Dry matter intake was significantly increased by CrPr $(P<0.05)$ but was not significantly affected by RPLM when fed for 5 wk near peak lactation (Table 2). Although neither RPLM nor CrPr significantly altered yields of milk or milk components, $\mathrm{CrPr}$ tended to increase ECM $(P=0.09)$ by $6 \%$ (Table 2$)$. In addition, we detected parity $\times \mathrm{CrPr}$ interactions for both DMI $(P=0.06)$ and milk protein yield $(P=0.04)$, in both cases indicating positive responses to $\mathrm{CrPr}$ in primiparous cows but not in multiparous cows (Figure $1 \mathrm{~A}$ and $\mathrm{B})$.

Several lines of evidence indicate that Cr supplementation during the periparturient period improves DMI and milk production (Hayirli et al., 2001; McNamara and Valdez, 2005). Hayirli et al. (2001) reported that supplementation of $0,3.9,8.3$, and $16.5 \mathrm{mg}$ of $\mathrm{Cr} / \mathrm{d}$ from Cr-methionine resulted in a linear increase in prepartum DMI. Besong et al. (1996) observed increased milk yield in the first $8 \mathrm{wk}$ of lactation in cows supplemented with $0.8 \mathrm{mg}$ of $\mathrm{Cr} / \mathrm{kg}$ of DMI as Cr-picolinate. Smith et al. (2005) found that supplementation of 0.03 or $0.06 \mathrm{mg}$ of $\mathrm{Cr} / \mathrm{kg}$ of $\mathrm{BW}^{0.75}$ increased DMI and milk yield in early lactation. In heat stress conditions, $\mathrm{Cr}$ supplementation from $3 \mathrm{wk}$ prepartum through $12 \mathrm{wk}$ postpartum improved postpartum DMI and increased milk yield by $6.7,12.3$, and $16.5 \%$ at 4,8 , and $12 \mathrm{wk}$ postpartum, respectively (Soltan, 2010). In these studies, feed efficiency was essentially unaffected, because the increases in milk yield and DMI in response to $\mathrm{Cr}$ supplementation paralleled each other.

The interaction of RPLM and CrPr affected milk protein content $(P=0.04$, Table 2$)$. Somewhat counterintuitively, in the absence of CrPr, RPLM decreased milk protein content $(P<0.01)$, but no effect of RPLM was detected in the presence of $\operatorname{CrPr}(P=0.77)$. Rumen-protected lysine and methionine also decreased the efficiency of $\mathrm{N}$ utilization for milk protein $(P=$ 0.05). Rumen-protected methionine (RPM) supplementation has been reported to increase milk protein content in many studies (Doreau and Chilliard, 1997; Leonardi et al., 2003; Pacheco et al., 2006), but not in others (Papas et al., 1984; Davidson et al., 2008). Fewer studies (Armentano et al., 1997; Rulquin and Delaby, 
Table 2. Effects of chromium propionate $(\mathrm{CrPr})$ and rumen-protected lysine and methionine (RPLM) on intake, productivity, and milk composition of lactating dairy cows

\begin{tabular}{|c|c|c|c|c|c|c|c|c|}
\hline \multirow[b]{2}{*}{ Item } & \multicolumn{2}{|c|}{ Control } & \multicolumn{2}{|c|}{ RPLM } & \multirow[b]{2}{*}{ SEM } & \multicolumn{3}{|c|}{$P$-value } \\
\hline & Control & $\mathrm{CrPr}$ & Control & $\mathrm{CrPr}$ & & $\mathrm{CrPr}$ & RPLM & $\mathrm{CrPr} \times \mathrm{RPLM}$ \\
\hline Milk yield, $\mathrm{kg} / \mathrm{d}$ & 40.5 & 43.7 & 42.4 & 43.3 & 1.44 & 0.14 & 0.61 & 0.39 \\
\hline Milk fat, $\%$ & 4.20 & 4.13 & 3.95 & 3.97 & 0.15 & 0.88 & 0.19 & 0.74 \\
\hline Milk protein, $\%$ & 2.75 & 2.67 & 2.62 & 2.68 & 0.04 & 0.66 & 0.09 & 0.04 \\
\hline Milk lactose, \% & 4.90 & 4.99 & 4.89 & 4.90 & 0.04 & 0.26 & 0.24 & 0.37 \\
\hline Fat yield, $\mathrm{kg} / \mathrm{d}$ & 1.68 & 1.81 & 1.66 & 1.70 & 0.07 & 0.27 & 0.37 & 0.58 \\
\hline Protein yield, $\mathrm{kg} / \mathrm{d}$ & 1.12 & 1.16 & 1.12 & 1.17 & 0.03 & 0.22 & 0.93 & 0.86 \\
\hline Lactose yield, kg/d & 2.01 & 2.17 & 2.09 & 2.15 & 0.07 & 0.15 & 0.74 & 0.54 \\
\hline Milk N efficiency, ${ }^{1} \%$ & 30.2 & 27.6 & 27.0 & 27.1 & 1.17 & 0.19 & $<0.05$ & 0.15 \\
\hline $\mathrm{ECM},{ }^{2} \mathrm{~kg} / \mathrm{d}$ & 43.1 & 46.3 & 43.1 & 44.9 & 1.47 & 0.09 & 0.62 & 0.65 \\
\hline ECM/DMI & 2.18 & 2.08 & 2.02 & 2.02 & 0.08 & 0.53 & 0.16 & 0.56 \\
\hline
\end{tabular}

${ }^{1} \mathrm{~N}$ efficiency $=$ milk protein $\mathrm{N}: \mathrm{N}$ intake.

${ }^{2} \mathrm{ECM}=(0.327 \times$ milk yield $)+(12.95 \times$ fat yield $)+(7.65 \times$ protein yield $) ;$ Dairy Record Management Systems $(2013)$.

1997) observed increased milk protein yield. Dietary supplementation of methionine or both methionine and lysine can significantly increase $\mathrm{N}$ utilization efficiency
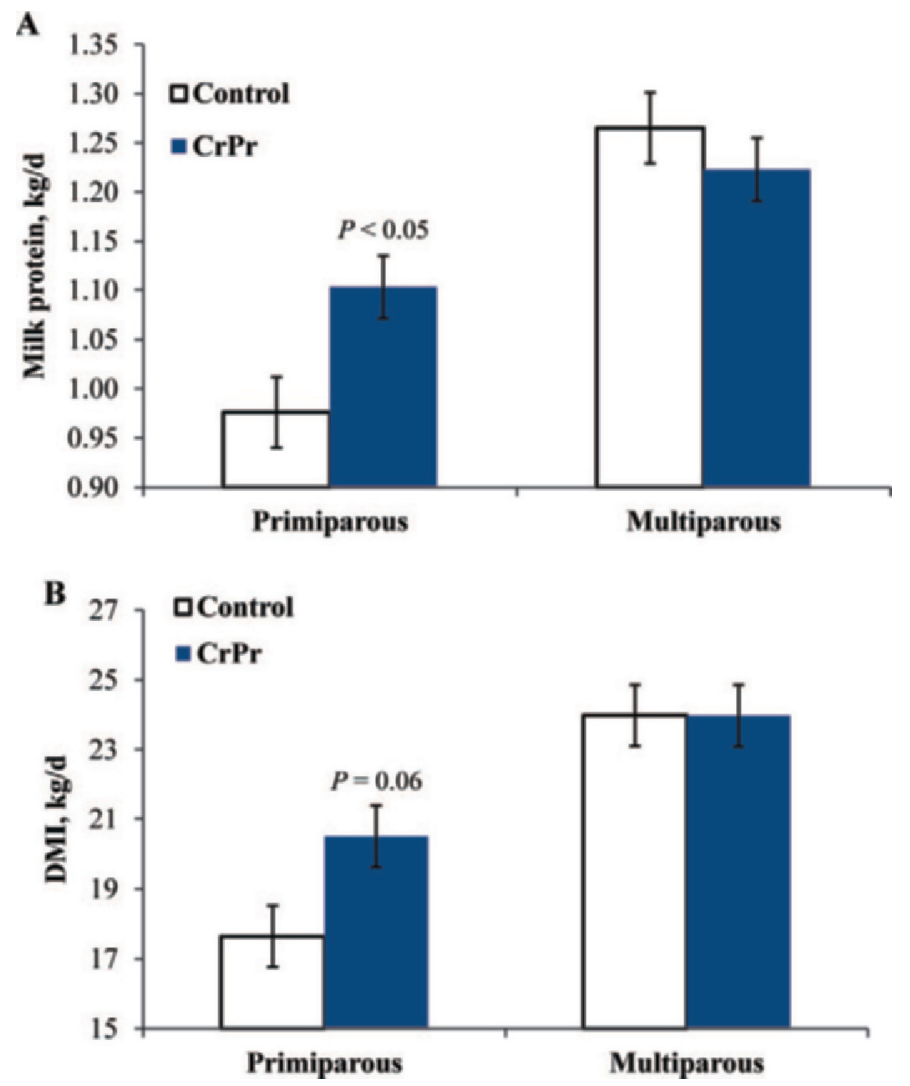

Figure 1. Interactions of chromium propionate $(\mathrm{CrPr})$ and parity for (A) milk protein yield and (B) DMI. Supplements were fed for 35 d near peak lactation, and DMI and milk production responses were analyzed by week throughout the study. Values are LSM \pm SEM; $\mathrm{n}=$ 10 to 13 . Color version available in the online PDF.
(Wang et al., 2010), but Noftsger and St-Pierre (2003) did not observe an improvement in $\mathrm{N}$ efficiency when they evaluated supplemental methionine in a digestibility trial. Likewise, varying results have been reported for milk and milk fat yields. In light of the inconsistent data, a meta-analysis (Patton, 2010) was conducted to investigate the effect of RPM supplementation on production. Those results indicated that addition of RPM to diets increased milk protein, both as percentage $(0.07 \%)$ and yield $(27 \mathrm{~g} / \mathrm{d})$, and slightly increased milk yield. However, DMI and milk fat percentage were slightly decreased. Therefore, although research is lacking on the simultaneous addition of both rumenprotected lysine and RPM on milk components, the decreased milk protein content by RPLM in our study was unexpected.

We observed a $\mathrm{CrPr} \times$ week interaction $(P=0.04)$ for lactose content, reflecting significantly greater lactose content (4.99 vs. $4.86 \pm 0.036 \%$ ) in response to $\mathrm{CrPr}$ during wk 1, with no differences observed from wk 2 on. Previous work has demonstrated enhanced glucose utilization in cattle supplemented with Cr (Sumner et al., 2007), consistent with the view that $\mathrm{Cr}$ acts primarily as an insulin sensitizing agent. However, we are not aware of other studies in lactating cows reporting increased milk lactose content in response to supplemental $\mathrm{Cr}$, so it is somewhat unclear what caused this response or why it was transient.

Intake of GE and DE and digestibility of GE and DM were similar across treatments $(P>0.10)$, and no treatment effects were detected for $\mathrm{NE}_{\mathrm{L}}$ balance, $\mathrm{BW}$ change, or BCS change (Table 3). The negative values for BW and BCS changes, which suggested that cows were in a catabolic state, appear to conflict with the positive calculated $\mathrm{NE}_{\mathrm{L}}$ balances. However, $\mathrm{BW}$ and 
Table 3. Effects of chromium propionate ( $\mathrm{CrPr}$ ) and rumen-protected lysine and methionine (RPLM) on energy balance of lactating dairy cow

\begin{tabular}{|c|c|c|c|c|c|c|c|c|}
\hline Item $^{1}$ & \multicolumn{2}{|c|}{ Control } & \multicolumn{2}{|c|}{ RPLM } & SEM & \multicolumn{3}{|c|}{$P$-value } \\
\hline $\mathrm{GE}_{\text {intake }}, \mathrm{Mcal} / \mathrm{d}$ & 92.8 & 100.8 & 98.1 & 101.1 & 4.18 & 0.10 & 0.42 & 0.46 \\
\hline $\mathrm{GE}_{\text {digested }}, \%$ & 81.4 & 82.0 & 82.2 & 81.1 & 1.43 & 0.86 & 0.97 & 0.51 \\
\hline DM digestibility, \% & 81.0 & 81.7 & 82.6 & 80.9 & 1.35 & 0.67 & 0.72 & 0.33 \\
\hline $\mathrm{NE}_{\mathrm{L}}$ balance, Mcal/d & 3.3 & 6.3 & 7.7 & 6.7 & 1.89 & 0.56 & 0.15 & 0.25 \\
\hline
\end{tabular}

${ }^{1} \mathrm{GE}=$ gross energy; $\mathrm{DE}=$ digestible energy.

BCS change data covered the entire 35-d experiment, whereas $\mathrm{NE}_{\mathrm{L}}$ balance was only determined on $\mathrm{d} 21$ and 35 . It is likely that many cows (mean 38 DIM at the start and 73 DIM at the end of the study) moved from negative energy balance to positive energy balance during the course of the study. Nevertheless, the accuracy of calculated $\mathrm{NE}_{\mathrm{L}}$ balance may have been limited due to biased estimations of fecal output with the ADIA marker. Dietary ADIA concentrations were relatively low in this experiment, potentially increasing variability in ADIA intake estimates, which could result in underestimated fecal mass and overestimated supply of energy. The magnitude of this potential bias was estimated by comparing $\mathrm{NE}_{\mathrm{L}}$ values calculated from measured energy digestibility versus model-derived $\mathrm{NE}_{\mathrm{L}}$ values based on ingredient characterization alone (Table 1). This comparison suggested that marker- based digestibility analysis may have overestimated ME supply by approximately $17 \%$. Regardless, relative treatment differences were valid because of the common basal diet, and the lack of an effect of $\mathrm{Cr}$ on energy balance is consistent with previous findings in early lactation (Smith et al., 2005; Sadri et al., 2009).

Plasma AA profiles are presented in Table 4. The proportion of lysine significantly increased $(P=0.05)$ and that of methionine tended to increase $(P=0.07)$ in response to RPLM. On the other hand, the proportion of threonine was significantly decreased by RPLM ( $P$ $<0.01)$. A tendency for a CrPr $\times$ RPLM interaction $(P=0.06)$ was observed for tryptophan, reflecting a decreased proportion of tryptophan by $\mathrm{CrPr}$ in the presence of RPLM $(P=0.03)$ but not in the absence of $\operatorname{RPLM}(P=0.64)$. The plasma lysine and methionine responses to RPLM were less than might have been

Table 4. Effects of chromium propionate ( $\mathrm{CrPr})$ and rumen-protected lysine and methionine (RPLM) on plasma amino acids on lactating dairy cows

\begin{tabular}{|c|c|c|c|c|c|c|c|c|}
\hline $\begin{array}{l}\text { AA, } \\
\text { molar } \% \text { of total AA }\end{array}$ & \multicolumn{2}{|c|}{ Control } & \multicolumn{2}{|c|}{ RPLM } & SEM & \multicolumn{3}{|c|}{$P$-value } \\
\hline Glycine & 15.57 & 15.07 & 14.98 & 13.92 & 1.10 & 0.48 & 0.42 & 0.80 \\
\hline Alanine & 10.88 & 11.84 & 11.72 & 11.53 & 0.43 & 0.37 & 0.52 & 0.18 \\
\hline Glutamine & 8.70 & 7.97 & 8.95 & 9.44 & 0.58 & 0.81 & 0.09 & 0.22 \\
\hline Leucine & 8.20 & 8.08 & 8.11 & 7.89 & 0.45 & 0.66 & 0.71 & 0.91 \\
\hline Citrulline & 4.40 & 4.65 & 4.08 & 4.18 & 0.34 & 0.32 & 0.23 & 0.81 \\
\hline Serine & 3.95 & 3.96 & 3.99 & 3.81 & 0.17 & 0.58 & 0.73 & 0.55 \\
\hline Arginine & 3.61 & 4.07 & 4.01 & 3.94 & 0.21 & 0.30 & 0.45 & 0.16 \\
\hline Lysine & 3.34 & 3.37 & 3.80 & 3.59 & 0.17 & 0.55 & 0.05 & 0.47 \\
\hline Glutamate & 3.02 & 2.91 & 2.78 & 2.85 & 0.28 & 0.91 & 0.47 & 0.67 \\
\hline Tyrosine & 2.14 & 2.15 & 2.30 & 2.23 & 0.10 & 0.75 & 0.22 & 0.65 \\
\hline Histidine & 2.10 & 2.09 & 1.89 & 2.05 & 0.07 & 0.28 & 0.09 & 0.25 \\
\hline Methionine & 0.95 & 0.99 & 1.06 & 1.01 & 0.04 & 0.93 & 0.07 & 0.12 \\
\hline Aspartate & 0.32 & 0.38 & 0.33 & 0.34 & 0.02 & 0.13 & 0.51 & 0.28 \\
\hline Total AA $(\mathrm{m} M)$ & 2.47 & 2.39 & 2.14 & 2.39 & 0.10 & 0.39 & 0.11 & 0.11 \\
\hline
\end{tabular}


expected, given the lack of increased milk protein yield. We observed increases of approximately $10 \%$ in lysine and $6 \%$ in methionine as a proportion of $\mathrm{AA}$ in response to estimated supplementation of 10 and $5 \mathrm{~g} / \mathrm{d}$, respectively. Similar supplementation rates have increased plasma concentrations by more than 30\% (Rogers et al., 1987), although without any change in milk protein yield in mid-lactation cows producing approximately $30 \mathrm{~kg}$ of milk/d. Compared with our work, the cows evaluated by Rogers et al. (1987) may have been more responsive to AA supplementation (in terms of plasma concentrations) because of lower microbial supply of $\mathrm{AA}$ and stable AA demands for protein synthesis. Few studies have evaluated responses to supplemental AA in cows during the transition from the catabolic state in early lactation to an anabolic state. Previous work has demonstrated that muscle repletion occurs during this stage of lactation and has suggested that increases in intestinally available methionine may enhance this process (Phillips et al., 2003). Whether or not such a response interferes with potential milk protein responses to bypass essential AA is unknown and may be a fruitful area of investigation, especially considering the complex interactions of AA supply and insulin signaling to influence both muscle deposition and milk protein synthesis (Bequette et al., 2001).

\section{CONCLUSIONS}

The supplementation of $\mathrm{CrPr}$ increased DMI and tended to increase ECM yield of peak-lactation cows when fed for a 5-wk period, and DMI and milk protein yield were particularly enhanced in primiparous cows. The inclusion of RPLM increased lysine and tended to increase methionine as a proportion of plasma AA but decreased the efficiency of $\mathrm{N}$ utilization for milk protein. These findings indicate that responses to dietary $\mathrm{Cr}$ in the dairy cow are not limited to early lactation.

\section{ACKNOWLEDGMENTS}

We thank Kemin Industries (Des Moines, IA) for providing funding to support this study. We thank the staff and student employees at the Kansas State University Dairy Teaching and Research Center (Manhattan) for animal care and technical assistance.

\section{REFERENCES}

AOAC International. 2000. Official Methods of Analysis. 17th ed. AOAC International, Arlington, VA.

Armentano, L. E., S. J. Bertics, and G. A. Ducharme. 1997. Response of lactating cows to methionine or methionine plus lysine added to high protein diets based on alfalfa and heated soybeans. J. Dairy Sci. 80:1194-1199.
Bequette, B. J., C. E. Kyle, L. A. Crompton, V. Buchan, and M. D. Hanigan. 2001. Insulin regulates milk production and mammary gland and hind-leg amino acid fluxes and blood flow in lactating goats. J. Dairy Sci. 84:241-255.

Besong, S., J. A. Jackson, C. L. Hicks, and R. W. Hemken. 1996. Effects of a supplemental liquid yeast product on feed intake, ruminal profiles, and yield, composition, and organoleptic characteristics of milk from lactating Holstein cows. J. Dairy Sci. 79:1654-1658.

Brake, D. W., E. C. Titgemeyer, M. J. Brouk, C. A. Macgregor, J. F. Smith, and B. J. Bradford. 2013. Availability to lactating dairy cows of methionine added to soy lecithins and mixed with a mechanically extracted soybean meal. J. Dairy Sci. 96:3064-3074.

Bryan, M. A., M. T. Socha, and D. J. Tomlinson. 2004. Supplementing intensively grazed late-gestation and early-lactation dairy cattle with chromium. J. Dairy Sci. 87:4269-4277.

Cochran, R. C., D. C. Adams, J. D. Wallace, and M. L. Galyean. 1986. Predicting digestibility of different diets with internal markers: Evaluation of four potential markers. J. Anim. Sci. 63:1476-1487.

Dairy Records Management Systems. 2013. DHI glossary. Accessed Jun. 17, 2013. http://www.drms.org/PDF/materials/glossary.pdf.

Dalbach, K. F., M. Larsen, B. M. L. Raun, and N. B. Kristensen. 2011. Effects of supplementation with 2-hydroxy-4-(methylthio)butanoic acid isopropyl ester on splanchnic amino acid metabolism and essential amino acid mobilization in postpartum transition Holstein cows. J. Dairy Sci. 94:3913-3927.

Davidson, S., B. A. Hopkins, J. Odle, C. Brownie, V. Fellner, and L. W. Whitlow. 2008. Supplementing limited methionine diets with rumen-protected methionine, betaine, and choline in early lactation Holstein cows. J. Dairy Sci. 91:1552-1559.

Doreau, M., and Y. Chilliard. 1997. Digestion and metabolism of dietary fat in farm animals. Br. J. Nutr. 78(Suppl. 1):S15-S35.

Gentry, L. R., J. M. Fernandez, T. L. Ward, T. W. White, L. L. Southern, T. D. Binder, D. L. Thompson, D. V. Horohov, A. M. Chapa, and T. Sahlu. 1999. Dietary protein and chromium tripicolinate in Suffolk wether lambs: Effects on production characteristics, metabolic and hormonal responses, and immune status. J. Anim. Sci. $77: 1284-1294$

Hayirli, A., D. R. Bremmer, S. J. Bertics, M. T. Socha, and R. R Grummer. 2001. Effect of chromium supplementation on production and metabolic parameters in periparturient dairy cows. J. Dairy Sci. 84:1218-1230.

Kegley, E. B., D. L. Galloway, and T. M. Fakler. 2000. Effect of dietary chromium-L-methionine on glucose metabolism of beer steers. J. Anim. Sci. 78:3177-3183.

Khalili, H., A. D. Foroozandeh, M. Toghyani, and G. Ghalamkari 2012. Reproductive performance by dairy cows fed supplemental chromium-methionine (Cr-Met) in transition period. Afr. J. Biotechnol. 11:16029-16033.

Leonardi, C., M. Stevenson, and L. E. Armentano. 2003. Effect of two levels of crude protein and methionine supplementation on performance of dairy cows. J. Dairy Sci. 86:4033-4042.

McNamara, J. P., and F. Valdez. 2005. Adipose tissue metabolism and production responses to calcium propionate and chromium propionate. J. Dairy Sci. 88:2498-2507.

Mertz, W. 1993. Chromium in human nutrition: A review. J. Nutr. 123:626-633.

NRC. 1997. The Role of Chromium in Animal Nutrition. Natl. Acad. Press, Washington, DC.

NRC. 2001. Nutrient Requirements of Dairy Cattle. 7th rev. ed. Natl. Acad. Press, Washington, DC.

Noftsger, S., and N. R. St-Pierre. 2003. Supplementation of methionine and selection of highly digestible rumen undegradable protein to improve nitrogen efficiency for milk production. J. Dairy Sci. 86:958-969.

Pacheco, D., C. G. Schwab, R. Berthiaume, G. Raggio, and H. Lapierre. 2006. Comparison of net portal absorption with predicted flow of digestible amino acids: Scope for improving current models? J. Dairy Sci. 89:4747-4757.

Papas, A. M., C. J. Sniffen, and T. V. Muscato. 1984. Effectiveness of rumen-protected methionine for delivering methionine postruminally in dairy cows. J. Dairy Sci. 67:545-552. 
Patton, R. A. 2010. Effect of rumen-protected methionine on feed intake, milk production, true milk protein concentration, and true milk protein yield, and the factors that influence these effects: A meta-analysis. J. Dairy Sci. 93:2105-2118.

Phillips, G. J., T. L. Citron, J. S. Sage, K. A. Cummins, M. J. Cecava, and J. P. McNamara. 2003. Adaptations in body muscle and fat in transition dairy cattle fed differing amounts of protein and methionine hydroxy analog. J. Dairy Sci. 86:3634-3647.

Rogers, J. A., U. Krishnamoorthy, and C. J. Sniffen. 1987. Plasma amino acids and milk protein production by cows fed rumen-protected methionine and lysine. J. Dairy Sci. 70:789-798.

Rulquin, H., and L. Delaby. 1997. Effects of the energy balance of dairy cows on lactational responses to rumen-protected methionine. J. Dairy Sci. 80:2513-2522.

Sadri, H., G. R. Ghorbani, H. R. Rahmani, A. H. Samie, M. Khorvash, and R. M. Bruckmaier. 2009. Chromium supplementation and substitution of barley grain with corn: Effects on performance and lactation in periparturient dairy cows. J. Dairy Sci. 92:5411-5418.

SAS Institute Inc. 2011. SAS/STAT 9.3 User's Guide. Version 9.3 ed. SAS Institute Inc., Cary, NC.

Smith, K. L., M. R. Waldron, J. K. Drackley, M. T. Socha, and T. R. Overton. 2005. Performance of dairy cows as affected by prepartum dietary carbohydrate source and supplementation with chromium throughout the transition period. J. Dairy Sci. 88:255-263.
Soltan, M. A. 2010. Effect of dietary chromium supplementation on productive and reproductive performance of early lactating dairy cows under heat stress. J. Anim. Physiol. Anim. Nutr. (Berl.) 94:264-272.

Spears, J. W., C. S. Whisnant, G. B. Huntington, K. E. Lloyd, R. S. Fry, K. Krafka, A. Lamptey, and J. Hyda. 2012. Chromium propionate enhances insulin sensitivity in growing cattle. J. Dairy Sci. 95:2037-2045.

Sumner, J. M., F. Valdez, and J. P. McNamara. 2007. Effects of chromium propionate on response to an intravenous glucose tolerance test in growing Holstein heifers. J. Dairy Sci. 90:3467-3474.

Van Soest, P. J., J. B. Robertson, and B. A. Lewis. 1991. Methods for dietary fiber, neutral detergent fiber, and nonstarch polysaccharides in relation to animal nutrition. J. Dairy Sci. 74:3583-3597.

Wang, C., H. Y. Liu, Y. M. Wang, Z. Q. Yang, J. X. Liu, Y. M. Wu, T. Yan, and H. W. Ye. 2010. Effects of dietary supplementation of methionine and lysine on milk production and nitrogen utilization in dairy cows. J. Dairy Sci. 93:3661-3670.

Wildman, E. E., G. M. Jones, P. E. Wagner, R. L. Boman, H. F. Troutt Jr., and T. N. Lesch. 1982. A dairy cow body condition scoring system and its relationship to selected production characteristics. J. Dairy Sci. 65:495-501. 